\title{
Desmoplastic Malignant Melanoma
}

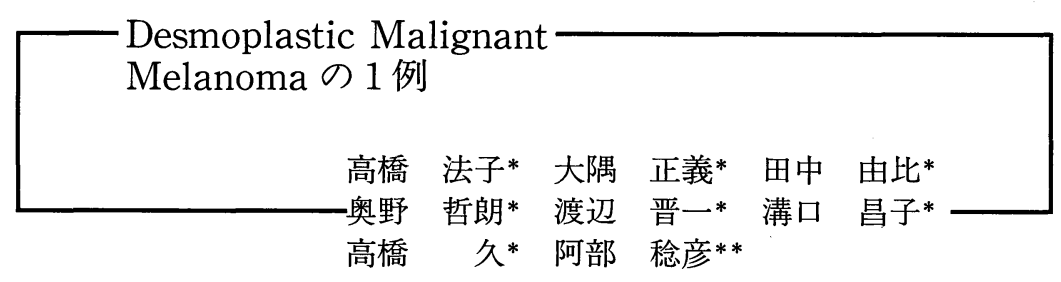

\section{Summary}

75 歳女性。昭和 50 年, 右足踵の皮膚覀性腫瘍のため右下腿切断術施行。昭和 63 年 6 月右 大腿前面の腫瘤に気付く。その後約 2 力月で手拳大に増大。組織学的に, 真皮深層から筋 膜にかけて比較的境界明瞭な腫場塊が存在し, 腫瑒細胞は異型性を示す線維芽細胞様細胞 からなり, 病理診断は fibrosarcoma であった。免疫組織化学的に S-100蛋白陽性であり, 1971年, Conley らが初めて提唱した desmoplastic malignant melanomaに一致するも のと思われ，若干の文献的考案を加え報告した。

\section{緒言}

Desmoplastic malignant melanoma (DMM) は malignant melanomaの稀な一型であり, 1971年 Conley ら ${ }^{1} に よ り$ 初めて提唱された疾 患概念である。本症は, $\mathrm{HE}$ 標本のみでの診断は 非常に困難であり fibrosis，invasive fibromatosis, fibrosarcoma 等と誤診されやす い特異な悪性黒色腫である。我々は, 色素病変 切除後13年目に生じた DMMの 1 例を経験し たので報告する。

* Noriko TAKAHASHI, Masayoshi OHSUMI, Yui TANAKA, Tetsuroh OKUNO, Shinichi WATANABE, Masako MIZOGUCHI, Hisashi TAKAHASHI：帝京大学皮虐科学教室（主 任：高橋 久教授)

** Toshihiko ABE：小川日赤病院皮膚科

症

例

患 者：75歳，女性

初 診: 昭和 63 年 9 月 13 日

主 訴: 右大腿前面上方内側部の腫瘤。

家族歴：特記すべきことなし。

既往歴：昭和 50 年 5 月，右足踵部の皮膚悪性 腫瘍のため, 右下腿切断術を施行。

現病歴：昭和63年，右大腿前面の腫瘤に気付 くも自覚症状がないため，放置していた。同年 9 月には手拳大にまで急激に増大および隆起が 認められるようになったため，小川日赤病院皮 膚科を受診した。既往歴より転移性皮膚悪性腫 瘍，臨床所見より間葉系腫瘍などを疑い診断治 療目的にて当院当科紹介となった。

現 症: 右大腿前面上方内側部に $12 \times 8.0 \times$ $2.0 \mathrm{~cm}$ の皮下腫瘤が存在した(図 1 )。表面皮膚 は淡紅色で多少の光沢が認められ，腫瘤は石様 硬に触知され境界は比較的明瞭であった。下床 との可動性は不良であり, 強く癒着しているも 


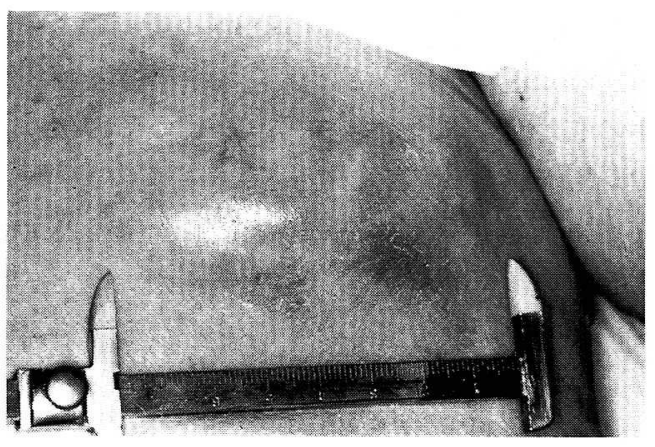

図 1. 初診時現症

のと思われた。所属リンパ節は触知しなかった。 自覚症状はなかった。一般臨床検查に特に異常 は認められなかった。胸部レ線, 異常なし。Ga シンチでは右大腿前面上方内側の病変部に一致 して取込みがあったが，他の部位には認められ なかった。

治 療：健常皮䖉を $5 \mathrm{~cm}$ 含め, 下床は筋膜 を全層性に，また腫瘤直下の長内転筋の一部と 浅鼠径リンパ節を en bloc として腫瘤を全摘出 後, mesh graft を施行した。術後, CYVADIC 療法 1 クール施行し, 現在術後 9 力月経過する も，局所再発および遠隔転移なく全身状態良好 である。

病理組織学的所見：摘出された腫瘤の割面は 乳白色を呈し境界は比較的明瞭な $6.0 \times 3.5 \times$ $4.0 \mathrm{~cm}$ の腫瘤であった。真皮深層から皮下脂肪 織および筋膜にかけて比較的境界明瞭な腫瘍塊 が存在し，その周囲にわずかな炎症性細胞浸潤 が見られた。腫瘍細胞は一部に striform pattern が認められ，間質に collagen の増生が存在 した。主体を占める腫犜細胞は主に紡錘型の線 維芽細胞様細胞からなり，核の大小不同・核分 裂像および異型性が散見された。HE 標本での 病理診断は fibrosarcomaであった（図 2 )。

免疫組織化学的所見：ホリマリン固定後, パ ラフィン包埋した切片を $\mathrm{ABC}$ 法にて染色し た。腫瘍細胞は, 核・細胞質ともに S-100蛋白 陽性（図 3 ）であり，S-100蛋白のサブユニッ

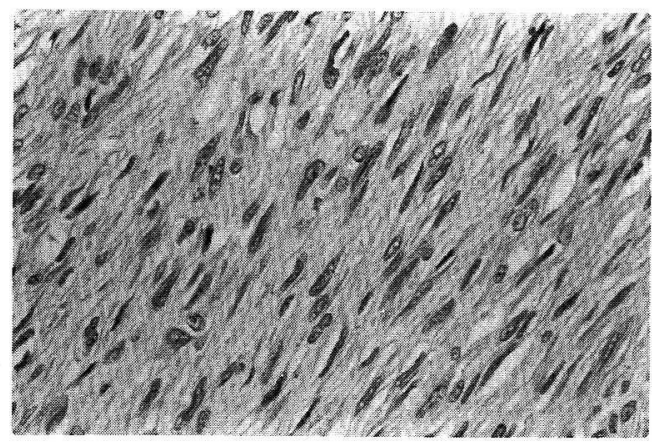

図 2. 右大腿における腫瘍組織像 ( $\mathrm{HE})$

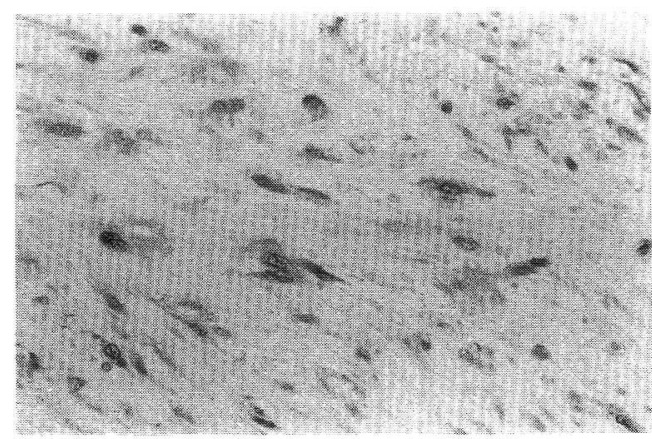

図 3．腫瘍組織の S - 100 蛋白陽性所見

トである， $\alpha$ 鎖・ $\beta$ 鎖について検討したところ、 ともに陽性所見を得たが， $\alpha$ 鎖により強い陽性 所見を得た。その他いくつかの抗体で免疫組織 化学的染色を行ったが, vimentinのみが陽性 で, keratin, neuron specific enolase (NSE), desmin, $\alpha_{1}$-antitrypsin, lysozyme, neurofilament, glial fibrillary acidic protein (GFAP) はすべて陰性であった。

電顕所見：辺縁にクロマチンが凝集した不規 則に入り込んだ核を有する細胞が腫瘍内に見ら れ, 細胞質には豊富な細胞内小器官が存在した。 検索した限り腫瘍細胞内には melanosome は 認められなかった。間質には microfibril と幼若 な collagen が認められ，また線維芽細胞様細胞 も多く存在した。また，一部の細胞質内に矢印 のごとく膠原線維の産生が認められた（図 4 ）。 


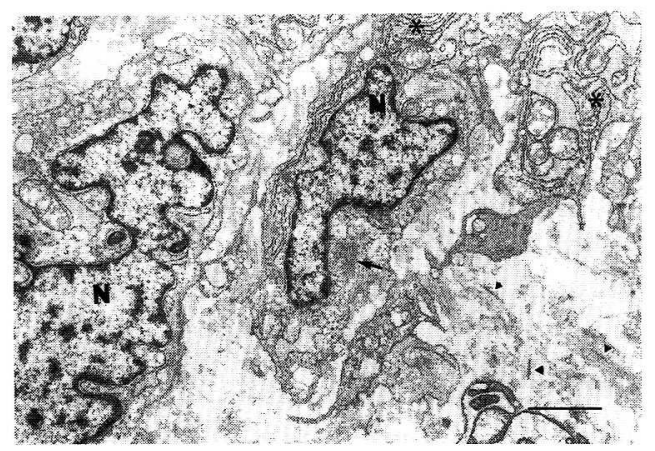

図 4.腫瘍組織の電顕像

腫瘍細胞は不規則に入り込んだ核 $(\mathrm{N})$ を有 し，また粗面小胞体 $(*)$ の上く発達した線維 細胞様細胞もみられた。一部の細胞では細胞 内に膠原線維の産生 (矢印)がみられ, 間質に は microfibril に囲まれた幼若な膠原線維 (矢 尻）が存在した。Barは $2 \mu \mathrm{m}$

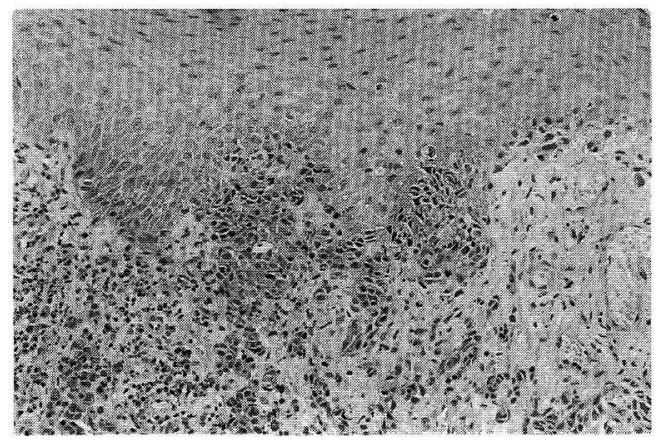

図 5，原発巣の組織像（HE）
以上より desmoplastic malignant melanoma (DMM) と考えられたので，昭和50 年の右足踵部の皮膚悪性腫湯についての標本を 取り寄せ再検討した。

右下腿切断するに至った病変の腫瘍巣は, 表 皮真皮境界部に異型メラノサイトの増殖と, 真 皮での胞体の明かるい異型性をもつ類円形細胞 からなる胞巣形成が認められた（図 5 )。標本は punch biopsyによるものであり，13年という長 期にわたる保存および組織切片が厚い等の悪条 件のために充分な検討は行えなかったが, tumor thickness $4 \mathrm{~mm}$ 以上より level $\mathrm{V}$, 新 stage 分類IIIの malignant melanoma と診断し た。

\section{考案}

DMM は1971年 Conley ら ${ }^{1)} よ り$ 初めて提 唱された malignant melanoma の特殊型であ $\eta$, 組織学的に無色素性紡錘型細胞が線維成分 の増殖（desmoplasia）を伴っているものをい $j^{2)}$ 。

DMM は HE 標本のみでの診断は非常に困 難であり，現在まで報告のあった DMM は，表 1 に示寸様に, fibromatosis ${ }^{1}$, atypical fibroxanthoma $^{3)}$, fibrosarcoma ${ }^{1) 4}$, malignant fi-

表 1.HE 標本での病理診断例

\begin{tabular}{|c|c|}
\hline 良性腫㾟 & 悪性腫㾟 \\
\hline keloid & fibrosarcoma \\
\hline fibroma & reticulum cell sarcoma \\
\hline hypertrophic scar & squamous cell carcinoma \\
\hline fibromatosis & malignant fibrous histiocytoma \\
\hline reactive hyperplasia & spindle cell squamous cell \\
\hline nodular fascitis & carcinoma \\
\hline fibrous histiocytoma & \\
\hline atypical fibroxanthoma & \\
\hline
\end{tabular}


brous histiocytoma ${ }^{5)}$, spindle cell squamous cell carcinoma ${ }^{6}$ 等と，様々な病名で診断されて いる。なかでも fibrosarcoma と誤診される事 が多いようである。しかも DMM では，電顕的 にもメラノゾームが認められることはまれで, また dopa 反応も陰性のことが多い。そのため 他の疾患として報告されている症例がかなり多 いのではないかと思われる。

自験例の場合， S-100蛋白陽性であったため DMM と診断できたが，他の間葉系腫瘍を否定 するためにいくつかの抗体で免疫組織化学的検 討を加えた。その結果 desmin 陰性から筋肉系 分化を示す腫瘍を否定し，また $\alpha_{1}$-antitrypsin, lysozyme 陰性から組織球系を，また NSE, GFAP, neurofilament 陰性から神経系を，keratin 陰性から上皮系分化を示す腫瘍を各々否 定することができた。また自験例では，S-100 蛋白のサブユニットである $\alpha$ 鎖・ $\beta$ 鎖について 検討したところ，ともに陽性所見を得たが， $\alpha$ 鎖により強い陽性所見を得た。これは，高橋ら ${ }^{7}$ の悪性黒色腫に対する検討結果と一致してい た。いずれにせよ自験例は，病理組織学的に fibrosarcoma であり，腫瘍細胞は S-100蛋白陽 性で，しかも13年と経過は長いが先行する色素 病変があったことは DMMに一致する所見で あった。

現在までの報告例をみると，DMM は原発巣 で診断される事は非常にまれである。それは原 発巣の細胞が，通常の悪性黒色腫と比べて異型 性が少なく，しばしば良性の色素病変と誤診さ れるためである。そのため，原発巣に対して不 適切な治療，すなわち電気焼灼・単純切除など が施され，局所再発もしくはリンパ節転移を生 じ，そこで初めて DMM と診断されることが多 い。この先行病変の色素細胞の異型性が少ない ことも，DMM の診断をより一層困難なものに している。

本症でみられるメラノーマ細胞の desmoplasiaの原因はまだ不明であるが，本来メラ ノーマ細胞は，培養により脱分化しやすいこと
が知られており，通常の培養では容易に色素産 生能を失い線維芽細胞様の形態をとる。また, 正常メラノサイトを長期間培養するとメラノ ゾームを失い形態的にも線維芽細胞様となる。 このことは，DMM では原発巣の悪性度が低い ため宿主を殺すことなく長期間生体内で増殖し 続けることが可能なため, メラノーマ細胞の形 態変化が起こる時間的余裕があり，そのため腫 瘍細胞が色素産生能を失い, 線維芽細胞様細胞 になると考えることも可能である。自験例のよ うに13年前の色素病変が原発巣とすると，13年 という長い時間はメラノ一マ細胞が線維芽細胞 様細胞に変化するのに充分であると思われる。 今のところ，本邦報告例は，自験例を含めわず か 7 例4889910)である。これは以上に述べたよう に，DMM の診断は通常の HE 標本だけでは困 難であり，相当数が見過ごされたためであると 思われる。今後間葉系腫瘍を診断するに当たっ て，光顕病理標本の検討だけでなく，少なくと も S-100蛋白等の免疫組織化学的検索を行うこ とが重要であり，これらの検討が行われていな い場合は，その診断には常に疑問を持つべきも のと思われる。今後，いろいろな症例に対して 免疫組織化学的検索が行われれば DMM の確 定診断がなされ，多くの症例の集積が可能とな ク，そのことにより desmoplasia の病因を解明 する糸口となる可能性があるものと考える。

\section{文献}

1) Conley, J., Lattes, R. et al: Desmoplastic malignant melanoma (A rare variant of spindle cell melanoma). Cancer, 28 : 914-936, 1971.

2）中川秀巳：現代皮膚科学体系，追補第 2 巻，中川 書店，東京，1987，48-52。

3) Labrecque, P.G., Hu, C., H. et al: On the nature of desmoplastic melanoma. Cancer, 38 : 1205-1213, 1976.

4）小林陽太郎, 宮里 肇, 他：皮䖉転移巣に Desmoplastic melanomaの所見がみられた悪性黒色腫 の1例. 臨皮, 34:229-235，1980.

5) Valensi, Q.J.: Desmoplastic malignant melanoma. Cancer, 43 : 1148-1155, 1979. 
6) Berry, R.B., Subbuswamy, S.G., et al : Desmoplastic malignant melanoma. Brit. J. Plast. Surg. 35 : 324-327, 1982.

7）高橋博之, 前田香折, 他：悪性黒色腫の免疫組織 化学的検討. 皮臨, $30: 1273-1279,1988$.

8）島田真路, 山田 清, 他: Desmoplastic malig- nant melanoma. 皮臨, $25: 353-361,1983$.

9) 朔 敬, 高橋 弘, 他: 口腔無色素性悪性黒色腫. 癌臨, $29: 424-432,1983$.

10) Hidemi Nakagawa, Lee, A.Y. et al: Desmoplastic malignant melanoma. J. Derm., 15 : 161-167, 1988. 